\title{
Article
}

\section{Researching violence with children: Experiences and lessons from the UK and South Africa}

Radford, Lorraine, Lombard, Nancy, Franziska, Meinck, Katz, Emma and Mahati, Stanford Taonatose

Available at http://clok.uclan.ac.uk/17040/

Radford, Lorraine ORCID: 0000-0002-6095-3845, Lombard, Nancy, Franziska, Meinck, Katz, Emma and Mahati, Stanford Taonatose (2017) Researching violence with children: Experiences and lessons from the UK and South Africa. Families, Relationships and Societies . ISSN 2046-7435

It is advisable to refer to the publisher's version if you intend to cite from the work. http://dx.doi.org/10.1332/204674317X14861128190401

For more information about UCLan's research in this area go to http://www.uclan.ac.uk/researchgroups/ and search for <name of research Group>.

For information about Research generally at UCLan please go to http://www.uclan.ac.uk/research/

All outputs in CLoK are protected by Intellectual Property Rights law, including Copyright law. Copyright, IPR and Moral Rights for the works on this site are retained by the individual authors and/or other copyright owners. Terms and conditions for use of this material are defined in the policies page.

\section{CLoK}

Central Lancashire online Knowledge www.clok.uclan.ac.uk

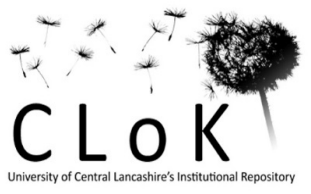




\title{
article
}

\section{Researching violence with children: Experiences and lessons from the UK and South Africa}

\author{
Lorraine Radford, ${ }^{1}$ Iradford@uclan.ac.uk \\ University of Central Lancashire, Preston, Lancashire, UK \\ Nancy Lombard, nancy.lombard@gcu.ac.uk \\ Glasgow Caledonian University, UK \\ Franziska Meinck, franziska.meinck@spi.ox.ac.uk \\ University of Oxford, Oxford, UK \\ Emma Katz, katze@hope.ac.uk \\ Liverpool Hope University, Liverpool, UK \\ Stanford Taonatose Mahati, Stanford.Mahati@wits.ac.za \\ University of Witwatersrand, Johannesburg, South Africa
}

\begin{abstract}
The impact of violence on children's health and development has had growing attention in global and national politics. Research on children's experiences of violence has increased in recent years, and this article aims to add to this literature by highlighting key messages and learning points from the experiences of researchers who have worked with children and violence across the different contexts of the UK and South Africa. As qualitative and quantitative researchers, our concepts, aims, methods, resources and approaches were very different, but we all faced similar challenges in working with children and violence in contexts where adults' views about what violence counted predominated. We argue that children's participation in research and highlighting children's own understandings, agency and negotiations in relation to violence are crucial for challenging sometimes unhelpful taken-for-granted views about the impact of violence on children's lives.
\end{abstract}

key words childhood $\cdot$ cross-national research $\cdot$ child abuse

- family violence $\cdot$ domestic violence $\cdot$ independent migrant children

\section{Introduction}

Violence against children is a global problem with a significant impact on the health and wellbeing of children and young people (Pinheiro, 2006). In 2012 it was estimated that there were 95,000 children who died as a result of homicide, accounting for one out of every five homicides across the world in that year (UNICEF, 2014). While many international conventions and treaties, such as the 1989 United Nations 
Convention on the Rights of the Child (UN CRC), have set out state responsibilities to protect children from all forms of violence, monitoring exercises on progress and implementation indicate that much remains to be done (WHO, 2014). Uncovering the extent, nature and impact of violence against children across different contexts continues to be a challenge for policy, practice and for research.

This article brings together researchers who have employed different methods of researching children and young people's experiences of violence and adversity across the different contexts of the UK and South Africa. It builds on our previous individual work on theory and methods of research with children (Radford, 2012; Cluver et al, 2013; Lombard, 2013, 2014, 2015; Katz, 2015a, 2015b, 2016; Meinck et al, 2015a). Young people's position in childhood has an impact on how they construct and understand violence, and how adults position children - in an often contradictory way - as 'victims', 'perpetrators', 'survivors', 'agents' and 'participants' in research. Drawing on five different studies (see Table 1), we reflect on learning from our experiences of conducting research with children, how children are positioned as research participants, as social actors, and how adult researchers recount what they say.

Although as researchers each of us approached our particular studies using different methodologies, informed by a range of different concepts and theoretical approaches, we all had the shared understanding of how cultural and social contexts contribute to experiences and constructions of 'childhood' and 'violence'. James and Prout (1997) theorise childhood as both a social institution and as being defined by the actions of individual children. For Jenks, childhood is a,

... social status delineated by boundaries that vary through time and from society to society but which are incorporated within the social structure and thus manifested through and formative of certain typical forms of conduct. Childhood then always relates to a particular cultural setting. (Jenks, 1996:7)

As such, it is important not to imply that the definitions and experiences of children and young people are timeless and universal, or that age defines experience and knowledge. The concepts of 'childhood' and 'age' vary across time, space and cultures (Christensen and James, 2000), with childhood embraced as a social construction 'constituted at a particular moment in time and point in space' (James and Prout, 1997: 28). Understanding the context from which knowledge about children's different experiences of 'childhood' and 'violence' are produced was a feature of all the five research studies. Culture, time, space and place influenced, in different ways, how we each approached the design, conduct and interpretation of meanings derived from our research in the different contexts in which we were working. Proximity and distance, as temporality (age, notions of childhood and adulthood) and spatiality (home, public space, location of violence, etc) (Lombard, 2013) were concepts that had resonance for each of the studies.

The World Health Organization (WHO) has defined violence as being:

... the intentional use of physical force or power, threatened or actual, against oneself, another person, or against a group or community, that either results in or has a high likelihood of resulting in injury, death, psychological harm, maldevelopment, or deprivation. (quoted in Krug et al, 2002, 1084) 
Violence may be physical, sexual, psychological or involve deprivation and neglect.

Another shared concern among all contributors was a commitment to hearing what children and young people themselves say about violence, recognising their agency (James et al, 1998) as participants in the research process as well as in relation to making sense of their experiences of victimisation and as perpetrators. Social constructions of childhood in Western philosophy and social policy have drawn extensively on the positioning of children as either vulnerable, as 'victims' of violence and abuse, or as dangerous (Jenks, 1996; Radford, 2012). The positioning of children as victims, which is reflected in the 1989 UN CRC, tends to be very dominant in shaping how governments and non-governmental organisations (NGOs) in the global South frame children (UNICEF,1989). This poses a challenge for research on violence against children as 'Child abuse is real but it is equally a device for constituting a reality' (Jenks, 1996: 95). Perceptions of violence change over time, across cultures, according to context and according to whose voices are heard when defining what is legitimate, what is normalised or what counts as violence or abuse. Adults have historically shaped the definitions of crime and violence so that across time, different settings, contexts and relationships, many acts of violence towards children and young people have not been recognised as 'crimes' or 'violence' (Finkelhor, 2008; Radford, 2012).Violent and abusive adults in particular try to deny, cover up or define their behaviour as something other than violence. Consequently this makes the process of identifying and recognising child abuse and neglect within research and in child protection services more difficult (Brandon et al, 2008). Adult researchers occupy positions of power when reporting what children say about their experiences of violence. Adult perspectives on what type of violence and which incidents matter have predominated research.

On the other hand, in some contexts, as we show, concerns about children's vulnerability as victims of violence in need of adult protection can divert attention from children's own strategies, capacities and agency. Some forms of violence against children, sexual abuse or sexual exploitation especially, evoke strong emotional responses from adults. Concerns about children's vulnerability to violence can shift the focus away from the multiple and compounding adversities and challenges a child may face, such as poverty, discrimination or lack of citizenship. Keeping sight of how context would influence what adult researchers hear and understand and what children are able to say was relevant for all contributors. Each of us faced similar challenges in identifying approaches that were relevant, meaningful, ethical and respectful for researching violence against children across the different contexts in which we were working.

\section{The five studies}

In the rest of this article we draw on experiences gained from five different research studies to highlight the importance of using appropriate theoretically informed methodologies when talking to young people about violence. The five studies had different objectives, resources and constraints. Two were large-scale epidemiological surveys carried out by research teams, one with a sample drawn from the general population in the UK (Radford et al, 2011, 2013) and the other conducted in two South African provinces: Mpumalanga and Western Cape (Meinck et al, 2015a, 2015b, 2016).Three of the studies were conducted by solo researchers and employed 
in-depth qualitative methods. Two of these took place in the UK and one in South Africa. Lombard explored children's perceptions of men's violence towards women. Katz $(2015 b, 2016)$ interviewed mothers and children about how living through domestic violence had affected their mother and child relationships. Mahati (2015) used ethnographic methods in a South African border town to research aid workers and independent migrant children's understandings of childhood and vulnerability (an independent migrant child is a child who is living apart from or who has no adult carers). Table 1 summarises the key features of the five studies.

Despite the differences in design, purpose, methods and contexts, similar issues emerged causing us all to confront in some way our personal understandings of researching violence and childhood. We discuss:

Table 1: The five case studies

\begin{tabular}{|c|c|c|c|c|c|}
\hline Title & Author & Purpose & Methods & Sample & Context \\
\hline $\begin{array}{l}\text { Young Carers } \\
\text { Study }\end{array}$ & $\begin{array}{l}\text { Franziska } \\
\text { Meinck }\end{array}$ & $\begin{array}{l}\text { Investigate } \\
\text { prevalence, } \\
\text { incidence, risks and } \\
\text { impact of HIV and } \\
\text { violence as well } \\
\text { as access barriers } \\
\text { to abuse response } \\
\text { services }\end{array}$ & $\begin{array}{l}\text { Epidemiological } \\
\text { prospective } \\
\text { survey of } \\
\text { young people } \\
\text { using assisted } \\
\text { paper-based } \\
\text { questionnaires } \\
\text { followed up one } \\
\text { year later }\end{array}$ & $\begin{array}{l}3,515 \\
\text { vulnerable } \\
\text { children and } \\
\text { young people } \\
\text { aged } 10-17\end{array}$ & $\begin{array}{l}\text { Two South } \\
\text { African } \\
\text { provinces of } \\
\text { Mpumalanga } \\
\text { and Western } \\
\text { Cape }\end{array}$ \\
\hline $\begin{array}{l}\text { Child } \\
\text { victimisation in } \\
\text { the UK }\end{array}$ & $\begin{array}{l}\text { Lorraine } \\
\text { Radford }\end{array}$ & $\begin{array}{l}\text { Investigate } \\
\text { prevalence, risks } \\
\text { and impact of past } \\
\text { year and lifetime } \\
\text { experiences } \\
\text { of childhood } \\
\text { victimisation and } \\
\text { help-seeking }\end{array}$ & $\begin{array}{l}\text { Epidemiological } \\
\text { cross-sectional } \\
\text { household- } \\
\text { based } \\
\text { survey using } \\
\text { interviewer- } \\
\text { assisted } \\
\text { and audio } \\
\text { computer- } \\
\text { assisted self- } \\
\text { interviewing } \\
\text { techniques }\end{array}$ & $\begin{array}{l}6,196 \\
\text { participants } \\
\text { randomly } \\
\text { selected from } \\
\text { UK household } \\
\text { postal address } \\
\text { file; } 2,160 \\
\text { were parents } \\
\text { of children } \\
\text { aged } 0-10, \\
2,275 \text { were } \\
\text { children and } \\
\text { young people } \\
\text { aged } 11-17, \\
1,761 \text { were } \\
\text { young adults } \\
\text { aged } 18-24\end{array}$ & $\begin{array}{l}\text { All regions } \\
\text { of the UK }\end{array}$ \\
\hline $\begin{array}{l}\text { Domestic } \\
\text { violence and } \\
\text { mother-child } \\
\text { relationships }\end{array}$ & $\begin{array}{l}\text { Emma } \\
\text { Katz }\end{array}$ & $\begin{array}{l}\text { Investigate } \\
\text { the impacts of } \\
\text { domestic abuse } \\
\text { on supportiveness } \\
\text { between abused } \\
\text { mothers and their } \\
\text { children, focusing } \\
\text { on children and } \\
\text { mothers' agency }\end{array}$ & $\begin{array}{l}\text { In-depth } \\
\text { face-to-face } \\
\text { semi-structured } \\
\text { interviews, } \\
\text { informed by the } \\
\text { feminist ethic } \\
\text { of care and } \\
\text { child-centred } \\
\text { approaches }\end{array}$ & $\begin{array}{l}\text { Volunteer } \\
\text { sample of } 15 \\
\text { mothers and } \\
15 \text { children } \\
\text { and young } \\
\text { people } \\
\text { aged 10-20 } \\
\text { recruited from } \\
\text { domestic } \\
\text { violence } \\
\text { services }\end{array}$ & $\begin{array}{l}\text { Domestic } \\
\text { violence } \\
\text { services } \\
\text { in the } \\
\text { Midlands } \\
\text { region of } \\
\text { England }\end{array}$ \\
\hline
\end{tabular}




\begin{tabular}{|c|c|c|c|c|c|}
\hline Title & Author & Purpose & Methods & Sample & Context \\
\hline $\begin{array}{l}\text { Young people's } \\
\text { understandings } \\
\text { of men's } \\
\text { violence against } \\
\text { women }\end{array}$ & $\begin{array}{l}\text { Nancy } \\
\text { Lombard }\end{array}$ & $\begin{array}{l}\text { Investigate } \\
\text { young people's } \\
\text { understandings } \\
\text { of men's violence } \\
\text { against women }\end{array}$ & $\begin{array}{l}\text { Qualitative and } \\
\text { participatory } \\
\text { methods that } \\
\text { included an } \\
\text { exploratory } \\
\text { questionnaire } \\
\text { and friendship- } \\
\text { based } \\
\text { focus group } \\
\text { discussions } \\
\text { using vignettes }\end{array}$ & $\begin{array}{l}89 \text { children } \\
\text { and young } \\
\text { people } \\
\text { aged } 11-12 \\
\text { recruited from } \\
\text { five primary } \\
\text { schools }\end{array}$ & $\begin{array}{l}\text { Glasgow, } \\
\text { Scotland }\end{array}$ \\
\hline $\begin{array}{l}\text { Migration, } \\
\text { childhood and } \\
\text { vulnerability }\end{array}$ & $\begin{array}{l}\text { Stanford } \\
\text { Mahati }\end{array}$ & $\begin{array}{l}\text { Explore aid workers } \\
\text { and independent } \\
\text { migrant children's } \\
\text { understandings of } \\
\text { 'childhood' and } \\
\text { 'vulnerability' }\end{array}$ & $\begin{array}{l}\text { Ethnographic. } \\
\text { Field-based } \\
\text { observations } \\
\text { and interviews }\end{array}$ & $\begin{array}{l}\text { Volunteer } \\
\text { sample of } \\
\text { approximately } \\
20 \text { aid workers } \\
\text { and } 100 \\
\text { independent } \\
\text { migrant } \\
\text { adolescents } \\
\text { from } \\
\text { Zimbabwe } \\
\text { recruited in a } \\
\text { border town }\end{array}$ & $\begin{array}{l}\text { Musina, } \\
\text { a South } \\
\text { African } \\
\text { border town } \\
\text { with high } \\
\text { levels of } \\
\text { violence and } \\
\text { crime }\end{array}$ \\
\hline
\end{tabular}

- How different ways of conceptualising children and adults inform the methods that we used, the questions that we asked, and the ways that we produce and understand findings.

- The different contexts in which research with children takes place and how methods of participation influence what can be done and our perceptions of meanings.

- The view that research with children on violence is inevitably difficult, harmful and young people are reluctant to take part.

- What violence in children's lives gets discussed in research, and how this relates to the positioning of 'childhood' and 'violence' in different contexts.

\section{Asking about violence: child victimisation in the UK}

All contributors to this article faced the problem of asking children and young people about experiences of violence in a context where what is recognised as childhood violence has been largely defined by adults. The purpose of Radford's study was to conduct a survey of children's experiences of abuse and neglect to measure the prevalence, impact, risk and protective factors and sources of help or support accessed. The survey was to be conducted in randomly selected households across the UK. This raised ethical issues regarding the safety and privacy of child informants as well as methodological issues about who to ask, what to ask and how to ask.

Who should be asked about experiences of violence in childhood is now a less contentious area of debate in research. Earlier research on violence in childhood was largely based on the accounts of adults, partly due to the belief that it would be 'unethical' to ask children themselves (Cawson et al, 2000). Recognition of children's rights has encouraged more direct research with children and a growing awareness that the ethical issues are important but can be addressed, especially if children themselves 
have meaningful participation in the research design. Radford's research was committed to this direct approach. Parents of children aged under 11, children aged 11-17 and their parent and young adults aged 18-24 were interviewed. As described in other publications (Radford and Ellis, 2012), a rigorous, ongoing process of ethical scrutiny was set up.Young survivors gave expert advice on ethical procedures for follow-up and support for children at risk. Support for children, young people and adults was given through an established network of contacts with Childline, the NSPCC National Helpline, independent counselling and child protection services.

How and what to ask children in a survey is crucially important as the questions asked limit what can be said, raising the possibility that children are only able to give partial accounts of their experiences. Questions can often be framed by an 'adultist' agenda rather than by issues that matter to young people themselves. A number of systematic reviews of the global prevalence of violence against children have been undertaken (for example, by Barth et al, 2013; Stoltenborgh et al, 2013). These show wide variations in findings, and there is consensus that this is mostly due to the conceptual and methodological differences that exist across different studies. Lower rates of violence against children are typically found if definitions of violence employed in surveys are narrow (Andrews et al, 2004). Many studies have focused on just one type of behaviour, for example, a child's exposure to domestic violence (Meltzer et al, 2009) or parental violence excluding physical discipline (Stoltenborgh et al, 2013), yet it is increasingly recognised that different types of violence may co-exist and overlap (Finkelhor et al, 2009). While much research on child abuse and neglect has focused on violence from caregivers or from adults, child protection policy and practice increasingly recognises that for a considerable proportion of cases of sexual and intimate partner violence towards children and young people, it is peers who are responsible (Barter and Berridge, 2010). Lower prevalence rates for children's experiences of violence are found if the focus of a survey is 'child abuse and neglect' (seen largely as only violence by adults), 'child maltreatment' (which includes some violence by peers in the context of a relationship of responsibility, trust or power; see Krug et al, 2002), 'violence against children' (all acts adults define as being 'violent') or 'child victimisation' (all forms of interpersonal victimisation by adults or peers likely to cause potential or actual harm; see Finkelhor, 2008).Victimisation researchers argue that violence perpetrated by other young people is not necessarily less harmful than that perpetrated by adults, and there is evidence to support this (Arseneault et al, 2006; Finkelhor et al, 2006). As experiences of violence often have overlapping and accumulative impacts, it is important for prevention to study and understand how these influence children's vulnerabilities (Finkelhor et al, 2009).

The UK survey was therefore designed to ask children and young people about all their experiences of victimisation, during childhood and in the past year, building into the study questions about harm caused, help sought and overall wellbeing so that relationships between experiences, subjective wellbeing and outcomes could be explored. In a context where violence is unrecognised, children and young people may be unable to name their experiences as 'violence'. Following advice from a group of international academic experts, age-appropriate, standardised measures of child victimisation that ask directly about specific acts experienced and that have been validated in research were selected (Finkelhor et al, 2005). The measures were tested in advance first, with a group of children who had experienced a high level of 
violence, with parents, and then with over 300 participants from randomly selected households.

As was the experience for all contributors to this article, decisions about the method of asking about violence are influenced by context, practical, methodological and ethical considerations. Three common approaches have been taken in national surveys of violence against children - using an interviewer-administered questionnaire, a self-completion paper questionnaire and Computer-Assisted Self Interviewing (CASI) and Audio CASI (ACASI) methods, where the interviewee is handed a laptop computer and is asked questions on screen or via headphones for ACASI, and responds directly on screen rather than being directly asked by an interviewer. Each approach has advantages and disadvantages. Interviewer-administered questionnaires allow an interviewer to pick up and respond to the participant's own questions, uncertainties, concerns and any signs of distress. However, in the context of a home where the victim and perpetrator may both be living, the questions themselves could be difficult to ask, even if a perpetrator is not actually in the household at the time of interview. Asking a participant about experiences of violence in a private way may be less upsetting than asking them directly face-to-face. The ACASI and CASI methods have been used in other household surveys, notably the Crime Survey in England, and have shown higher rates of response for sensitive questions about violence than interviewer-administered methods (Mirlees-Black, 1995; Burton et al, 2015). The CASI method allows faster and simpler navigation through a complicated survey where many of the questions might not be relevant to an individual. ACASI gives the child some control over the interview process allowing them to skip questions, answer or not answer, without the adult interviewer knowing. Radford found the method also gave young people who wanted to talk in private about issues raised in the survey an opportunity to ask for this without alerting others who may have been present in the house.

The power relationship between an adult interviewer and child research participant is an important issue influencing what might be said in any research with children. Where a large number of interviews have to be gathered in a limited time frame, the ACASI method enables a private space to develop between child participant and adult interviewer. In this space there is scope for the child participant to have some agency and control over what is and is not said. There are many limitations in the data achieved from surveys with pre-defined questions, but setting up the research in the way described provided an opportunity for children and young people to tell us about the range of experiences of victimisation they had and what was harmful, thereby challenging some common assumptions about certain forms of victimisation, such as peer victimisation, being harmless. Asking about all types of victimisation also highlighted how children who experienced 'polyvictimisation', that is, several different types of victimisation, at home, at school and in the community, had the poorest outcomes (Radford et al, 2011). Asking about past year experiences further allowed the researchers to explore patterns of victimisation for different age groups and genders, challenging common assumptions that adolescents are less at risk. Other contributors to this article faced different constraints and had different opportunities influencing how they asked young participants about experiences of violence and how they positioned themselves as adult researchers working within the context of adultist child protection frameworks. The next case study of research by Meinck also 
found that children often want to be involved and to be asked their views about experiences of violence

\section{Positive aspects of research participation:Young Carers Study}

While all five studies considered the importance and practicalities of children's participation in research, Meinck's study, part of the Young Carers Study, is used to illustrate the benefits of participating in research on violence. Children's participation is a fundamental right, although in research, participation should be meaningful, respectful, ethical and safe for the children involved (Lansdown and O'Kane, 2014). This is particularly so for children who have experienced violence where there are risks associated with being publicly identified as a victim. Similar to the previous case study, Meinck and colleagues were tasked with collecting data on children's experiences of violence via a household survey, but in the low resource settings in rural and urban areas of South Africa. The Young Carers Study sought to investigate the impacts of HIV and violence on children in a prospective cohort of vulnerable adolescents. Prevalence, incidence, perpetrators, locations, risk factors of child abuse victimisation and barriers to services were examined. Children aged 10-17 ( $N=3,515$, $57 \%$ female) were recruited from four health districts in randomly selected census enumeration areas using door-to-door sampling in two provinces: Mpumalanga and Western Cape. Participants were re-interviewed a year later to investigate the temporality of predictors of abuse.

In contrast to the previous case study, participants in the Young Carers Study had limited access to support and advice services. Electricity was not always available, making it difficult to use CASI delivered via laptops or tablets, so paper-based questionnaires, designed as teen magazines, were used. General literacy levels within the population were low, so there were challenges in using a self-administered paper survey. Employing interviewers to help young people with the survey raised concerns from expert reviewers of social desirability bias - young people might give answers they thought the interviewer expected. Social norms about what counted as 'violence', what was acceptable, justifiable or an everyday experience, would influence what could be said. Furthermore, South Africa has a mandatory reporting law stipulating referrals for all children at risk of significant harm, and this might deter disclosure in interview.

However, following a pilot and consultation with child protection professionals and the study's teen advisory group, an interviewer-assisted approach was selected as the best option in this context. Young people completed a one-hour interviewerassisted questionnaire in the local language of their choice (Xhosa, Zulu, Sotho, Swati, English and Tsonga). Interviewers were selected for their empathy and trained in working sensitively with vulnerable children. Participants were interviewed in a place of their choosing, such as, under a secluded tree to ensure confidentiality where households offered little privacy. Participants were granted confidentiality throughout the study unless they were considered to be at risk of significant harm or requested help. In these instances, referral options were discussed with the young person, and their wishes were considered throughout the referral process. These processes were carefully planned and set up considering the often considerable disjuncture between ethics committee requirements and on-the-ground availability of services. Referral processes were designed to cater for the specific context in which services are often 
overburdened and service delivery hampered by overworked and under-resourced staff (Cluver et al, 2015). Thus, human resources and transport were made available by the research project to facilitate access. It was project policy to set up close collaborations with existing local services to insure sustainable use while recognising that accessing services would become more difficult for participants at the end of the project due to unavailability of transport. Children were accompanied to the services by their original interviewer, where appropriate and requested. This enabled them to navigate the various services and maintain a continuing relationship with the person they disclosed to in the first instance. In total, 664 referrals were made to a wide variety of services including child protection, HIV testing and counselling, antiretroviral adherence counselling, immigration, birth registration, infectious diseases, mental health, women's shelters and rape crisis.

Much has been said about the potential harm of conducting research with children and young people on sensitive topics such as violence, and university ethics committees typically focus on what cannot be done (Graham et al, 2012). The Young Carers Study found that there are positive aspects to children's participation in research on violence that need to be considered when weighing up a study's benefits and potential for harm. Previous investigations on child participation in research has shown the following benefits for young people (Lansdown and O’Kane, 2014):

- it can provide information and insights into children's lives to inform legislation and policy, services and outcomes;

- children empowered by participation can become effective advocates for the realisation of their own rights;

- children acquire skills and competencies through participation;

- $\quad$ it leads to better child protection because children involved are better able to articulate their concerns;

- it promotes civic engagement and active citizenship;

- it builds accountability and promotes good governance.

All of these potential advantages are relevant to children's participation in research on violence. Adult researchers' expectations regarding children's experiences of taking part in violence research may well change if they ask participants for feedback on positive and negative experiences. Asking about violence can improve child safety. Many child rape victims in the Young Carers Study disclosed their experiences for the first time to the research team. They felt comfortable to disclose because they had the undivided attention of an empathetic adult and did not have to fear judgement or victim blaming.

The other studies similarly found that children's participation in research on violence can be a positive experience. Radford found that the majority of children and young people reported their involvement in the survey had been positive and worthwhile (Radford and Ellis, 2012). Mahati helped children who wanted his assistance to report their problems to service providers but did not report a case if a child feared that doing so would compromise his or her security. In Katz's study children and mothers benefited from the opportunities the interviews gave them to identify ways in which they had supported each other through domestic violence. This was not something that the participants had given in-depth thought to before they were interviewed 
(Katz, 2015b), and it may have helped them to recognise their own strengths and abilities to play a positive role within their families.

Talking about violence can be a positive, empowering experience for children. It can help to challenge unhelpful assumptions about violence and shift norms or behaviour. As Lombard's research with children in schools shows, it can be helpful because it validates experiences and names them as 'violence'. Lombard found that when violence was not named by those in authority (usually teachers or parents), then the young people were more likely to normalise such behaviours. For the majority of young people 'real violence' was physical, resulted in injuries, happened in a public place, between adult men who were sanctioned (sent to jail). Children's experiences of violence were less 'real' as they generally lacked these essential elements. If this same sequence was replicated at school, for example, if boys physically fought in public, if they were told by teachers or playground assistants that their behaviour was wrong and were chastised for it, both boys and girls termed this 'real violence'. However, girls had been pushed, shoved, kicked, followed, called sexualised names by their male peers, but these experiences did not fit the standardised constellation structure of 'real' violence: age (adult), gender (man), space (public), action (physical) and crucially, official reaction or consequence. Time and time again the girls, when they approached teachers or those in authority, were dismissed for telling tales, ignored because of the 'trivial' nature of their complaint or relayed that old adage, 'he's only doing it because he likes you'. Girls' experiences were minimised and the behaviour normalised (Lombard, 2015).

Lombard's work shows the value of questioning violence as 'everyday interactions' that are normalised (Dobash and Dobash, 1992). The feminist project of 'naming' involves 'making visible what was invisible, defining as unacceptable what was acceptable and insisting what was naturalized is problematic' (Kelly, 1988: 139). All of the case studies discussed here confirmed the importance of the naming process for young people, enabling them to voice their own concerns, using their own language and on their own terms. Enabling children to name experiences as 'violence' helps us all to understand and challenge what has happened to them, to move 'private' acts into the public domain, and to shift the boundaries of acceptable and unacceptable behaviour.

\section{Conceptualising adults and children: domestic violence and mother-child relationships}

Katz's research with children and mothers illustrates how theory can inform the design of the research, the questions asked about experiences of violence, and how researchers position children in relation to these experiences. Katz's study of the relationship between mothers and children is situated within an area of research that has traditionally positioned both children and adult women as 'problem' victims of domestic violence (Radford and Hester, 2015). As Katz (2015a) explores, much previous research into domestic violence, children and mothers has focused on the adverse impact of abuse for children and the consequences of their mothers' (limited) capacity to parent. While it is, of course, urgently necessary to recognise and be prepared to act on the harm caused by men who are abusive towards children and partners, it is an unhelpful child protection strategy to ignore the agency and efforts already made by adults and children trying to cope. Katz (2015a) observed that 
within this literature on domestic violence and children, parent-child relationships are often constructed as unilateral dependency relationships in which children, who are vulnerable, are/should be receivers of care from the parent, most often the abused mother, who should provide it (Callaghan, 2015). The gendered nature of this positioning of mothers and children in the context of domestic violence is rendered neutral in much of the child protection literature where only 'parents' are mentioned. A child supporting a mother is often seen by adult researchers as a role reversal, 'parentification' and overburdening of children with adult responsibilities (Katz, 2015a). Drawing on knowledge gained from the fields of childhood studies and developmental psychology (Morrow, 2003; Oliphant and Kuczynski, 2011), Katz's starting point was that children are active agents within their families, and that mutually supportive parent-child relationships are commonplace within families.

Katz conducted in-depth semi-structured interviews with 30 participants (15 mothers and 15 children and young people aged 10-20) to explore whether mutual support between a parent and child was also commonplace in families affected by domestic violence. All of the participants had separated from perpetrators of domestic violence (the children's fathers/father figures), and were in the process of recovering from their experiences at the time of interview. Taking an approach that sought to understand children and mothers' agency and their strengths in the context of violence and adversity, Katz asked questions about how mothers and children actively supported one another's recovery after domestic violence (Katz, 2015b), and gave her participants the opportunity to discuss the positive and negative aspects of this support. Doing this enabled her to gain an understanding of how children felt about the practices of supportiveness in their mother-child relationships.

Children and young people's accounts did not support the unilateral dependency view of their relationship with mothers or the parentification thesis. Most of the young people interviewed by Katz spoke very positively about the close and mutually supportive nature of their mother-child relationships: "We've helped to make each other feel better; we've given each other support throughout the whole thing" (Grace, aged 14). Children's appreciation of mutually supportive mother-child relationships was particularly evident in their responses to the question: 'If you had to imagine a really good relationship between a child and a mother, what would it be like?'

'Bonded - she's always there when you need her, and you're always there when she needs you.' (Joe, age 14)

'Being able to trust them; being able to tell them what's going on in your life; being able to support each other through everything.' (Grace, age 14)

Katz's efforts to ask strengths-based questions also helped to increase many of the participants' sense that they were having a positive impact on their mother-child relationships. Some research participants realised during their interview how much they had done to support their mother-child relationship (2015b), and this potentially increased participants' sense of self-efficacy (Tew et al, 2012). By enabling children and young people to talk about their agency, Katz was able to propose that a more nuanced, bilateral model of mother-child relationships could usefully be adopted in future research with children and domestic violence. 
Taking account of children's agency in response to experiences of violence was a feature in different ways across the other four studies. Children and young people exercising their agency through help-seeking and support was a core theme for Radford, Lombard and Meinck. Questions about risks and protective factors, in addition to questions about the prevalence and impact of experiences of violence, were included in the surveys by Meinck (Meinck et al, 2015a) and by Radford (Radford et al, 2011). This enabled experiences of individual, relationship and communitylevel strengths to be investigated, with scope to inform safeguarding strategies that build on and enhance these strengths. Radford's research asked children and young people about help-seeking and included questions about their own actions and use of informal support such as peer networks, identifying the importance of peers in the process of recognition, naming abuse, resisting and finding help and support (Radford et al, 2011). Meinck's research had a longitudinal perspective, enabling her to re-interview participants 12 months after the initial survey to identify change over time and to establish temporality (Meinck et al, 2015b). From this emerged findings on informal, peer support, and a girl's own agency in establishing protective networks. Peer support acted as a protective factor against sexual violence for girls, and was found to moderate the relationship between baseline assault and subsequent sexual abuse.

Lombard's study showed support networks could develop as part of the research process. In talking about everyday sexism and harassment, the girls in her study were able to highlight that their experiences were not individual or isolated incidents. Girls were able to 'name' and recognise their own experiences from the narratives of their peers. This collective consciousness was a critical step in making sense of individual disadvantage and wider inequalities in the present and future lives of these 11-year-old girls.

\section{Violence in contexts of migration, childhood and vulnerability}

Like Katz, in Mahati's research young people's agency in the face of violence was a key area of concern. Mahati's study of childhood and vulnerability was situated in a South African border town, characterised by high levels of violence, poverty, unemployment and large numbers of undocumented economic migrants from Zimbabwe and other African countries. Using ethnographic methods, Mahati conducted interviews in situ (Anderson and Jones, 2009), cumulative, serial qualitative interviews (Murray et al, 2009), and observations with migrant children and young people, and with humanitarian aid workers. These methods led to independent migrant children being keen to participate in the study and reporting feeling empowered by the chance to discuss their experiences at their own pace, under their own terms and conditions.

Mahati's starting point was to develop an understanding of the types and nature of violence in the area (Mahati, 2015). One of the storylines that emerged told of independent migrant boys who worked as human smugglers sharing the workspace with adult smugglers and magumaguma ${ }^{2}$ around the South African and Zimbabwean border.They deceived migrants without proper documentation that it was safe to use pathways in the bush to cross the border (see Rutherford, 2008; Mahati, 2012, 2015). State and non-state actors, including independent children and migrants, narrated 'harrowing stories of kidnap, being stoned, stabbed by knives, savagely beaten up, robbed of all the money they had, raped, gang raped and hearing that migrants were killed by magumaguma' (Mahati, 2015: 23). Magumaguma often forced migrants to 
commit heinous crimes at gun or knife point against fellow migrants with independent children as witnesses or forced participants. In one incident,'a boy aged 15 was forced to have sex with his mother as the other siblings and migrants watched. Overwhelmed by shame, the boy soon after arriving disappeared from his family. Other migrants heard him vowing never to see his mother again. This encounter with magumaguma turned him into an independent migrant child' (Mahati, 2015: 24). Situations like this influenced independent children's perceptions of themselves as victims and participants in violent acts.

For humanitarian aid workers at the border, the way migrant children were represented and understood in terms of childhood and vulnerability was shaped by the violence they were exposed to or perpetrated. Mahati found contradictory approaches to childhood, gender and vulnerability among the humanitarian aid workers. The presence of independent children, particularly girls, in the border town often disturbed humanitarian workers, generated heated discussion among themselves and between them and the children. Sexual violence often dominated discussions on violence and crime. Young female migrant children were generally viewed as more vulnerable to violence and compelled to behave 'appropriately' or in girl/woman-like ways. Humanitarian workers were often quicker to intervene to protect migrant girls in violent spaces than migrant boys. Migrant boys were seen as less at risk, especially from sexual violence, when living in dangerous environments, stronger than girls and better able to protect themselves. Migrant boys often reinforced this point by making their own efforts to 'rescue' migrant girls by quickly reporting to intervention agents to place them in places of safety.

Aid workers often associated childhood with 'innocence', but understandings of childhood tended to be situational: they shifted between official and unofficial interactions with children. The dominant official position for aid workers was that children would behave in child-like and non-violent ways. But not all independent children behaved as expected, a situation that was at times normalised by aid workers during unofficial interactions with children. Some humanitarian workers tried to understand and sympathise with children who committed acts of violence, highlighting their innocence as children, lack of choices and structural inequalities. Faced with peer pressure, a critical shortage of food, jobs and pressure to send remittances to parents and siblings in Zimbabwe, some independent children were seen as engaged in 'survival violence'. Independent children's behaviour fell, as Droz said, 'outside traditional moral values and social structures, and [they] develop[ed] violent and illegal strategies to survive' (2006: 352).

Some children, by their own admission, said they engaged in violent criminal acts to eke out a living. But they did not see themselves as weak or as 'victims', labels they often embraced during official interactions with aid workers as they sought to access aid. "We might be children but we live at this border. We know how to survive here", explained a 13 -year-old boy. Thabo, aged 15 , said if migrants they were smuggling across the border tried to refuse or reduce the amount they were supposed to pay him, he often responded by speaking in a menacing voice. He also revealed that sometimes in the spirit of bravado, he took on the persona of magumaguma and threatened to stone migrants refusing to cooperate. The migrants, not sure of their surroundings in the security zone, would immediately honour the deal.

Undocumented migrants who ignored children's advice were violently robbed, raped, and even killed by magumaguma. The official position that the children who 
committed these dangerous acts of violence were victims of structural inequalities was difficult for aid workers to sustain. They rationalised that since these children were engaging in criminal and violent activities, they should be characterised as such. This worked to legitimise aid workers' non-intervention when they received reports of children being violently beaten up by the police. Independent migrant children who worked as human smugglers were seen as people who, due to 'self-destructive agency' (Gigengack, 2008: 216) and gullibility to peer pressure, made poor choices. Drawing from the dominant discourse of protecting children's 'best interests', this resulted in removing them from a corrupt and dangerous environment and sending them to 'places of safety' where aid workers assumed 'in loco parentis' status. But these intervention efforts and understanding of children's best interests were often rejected by some of these children as they meant removing them from their sources of livelihood, the primary reason for migrating to South Africa.This exposes the challenge related to understanding and dealing with independent children's vulnerability.

In a related matter, Mahati found tension between independent children and aid workers' understanding of situations, with the latter often viewing children's actions using the lens of internationally accepted norms of childhood (dependant, with family, needing protection), which sat uneasily with the context in which the children lived. Paradoxically, this lens shifted the focus from the interconnected structural inequalities (of violence, poverty, lack of citizenship, etc) towards 'expected' norms of behaviour for children (for example, non-violence). Enabling young people themselves to talk about their experiences challenged commonly held views of children, particularly those with 'out of home' childhoods (Mahati, 2015), as either victims or misguided perpetrators of violence, and opens the way to explore more nuanced and contextual approaches to understanding children's needs. This case study reinforces the point that researchers should position children as competent social actors and use methodologies that enable them to explore different and often contradictory life-worlds.

\section{Learning from collaboration}

Much has been learned in the past few years from the shift in focus from research about children towards research with children that recognises children as active subjects who shape the world in which we live. Lived experiences of childhood have an impact on how children and young people experience violence and understand it. These experiences are not homogeneous and are influenced by time, place and context. Reflecting on what we learned as adult researchers using different qualitative and quantitative methodologies and across different contexts has given us a greater appreciation of how things could be done differently. We all faced similar challenges over how to make the research child-friendly, how to make it participatory, how to deal with ethical issues, how to adapt it to the context in which we were working, and how to create an environment in which children and young people could talk or have a voice. While researchers have rightly stressed the ethical risk of harm to children raised by research about violence, it is important to also take into account that having the opportunity to name experiences as violence can be a positive and empowering experience. Researchers need to ask children and young people more often about how they feel about having taken part in research. For each of us, children's participation in the design and creation of the research was crucial for understanding the context and for challenging taken-for-granted views about the nature of violence, the impact 
on children and their relationships with peers and with adults. In particular, whatever methods were used for the research, highlighting children's agency in violence helped us to ask questions about their own understandings, resources and coping responses in context, opening doors to new knowledge that can inform better prevention and response. This is crucial for informing policy and practice responses in all settings, but especially where access to support is limited.

\section{Notes}

${ }^{1}$ Corresponding author.

${ }^{2}$ Mostly male criminals who way-lay undocumented migrants using illegal entry points on both sides of the Limpopo River, and violently rob people of their valuables such as mobile phones, clothes and money.

\section{Acknowledgements}

The authors would like to thank the British Council for funding the researcher links meeting on 'Violence Against Women and Children in Diverse Contexts', and the University of Witwatersrand for hosting the event.

\section{References}

Anderson,J,Jones, K, 2009, The difference that makes to methodology: Uncovering the 'lived space' of young people's spatial practices, Children's Geographies 7, 3, 291-303 Andrews, G, Corry, J, Slade, T, Issakidis, C, Swanston, H, 2004, Child sexual abuse, in M Ezzati, AD Lopez, A Rodgers and C Murray, eds, Comparative quantification of health risks: Global and regional burden of disease attributable to selected major risk factors, vol 2, Geneva: World Health Organization, 1851-940

Arseneault, L, Walsh, E, Trzesniewski, K, Newcombe, R, Caspi, A, Moffitt, TE, 2006, Bullying victimization uniquely contributes to adjustment problems in young children: A nationally representative cohort study, Pediatrics 118, 130-8

Barter, C, Berridge, D, eds, 2010, Children behaving badly?, Chichester: John Wiley \& Sons

Barth, J, Bermetz, L, Heim, E, Trelle, S, Tonia,T, 2013, The current prevalence of child sexual abuse worldwide:A systematic review and meta-analysis, International.Journal of Public Health 58, 469-83

Brandon, M, Belderson, P, Warren, C, Howe, D, Gardner, R, Dodsworth, J, Black, J, 2008, Analysing child deaths and serious injury through abuse and neglect: What can we learn? A biennial analysis of serious case reviews 2003-2005, London: Department for Education

Burton, P,Ward, C,Artz, L, Leoschut, L, 2015, The Optimus Study on child abuse, violence and neglect in South Africa, Cape Town: Optimus Foundation

Callaghan, J, 2015, Mothers and children? Representations of mothers in research on children's outcomes in domestic violence, Psychology of Women Section Review 17, 13-20

Cawson, P, Wattam, C, Brooker, S, Kelly, G, 2000, Child maltreatment in the United Kingdom, London: NSPCC

Christensen, P, James, A, 2000, Research with children: Perspectives and practices, London: Falmer Press 
Cluver, L, Boyes, M, Meinck, F, 2013, Caregiver consent for child participation in research: Reaching and protecting the most vulnerable, in A Graham, M Powell, N Taylor, D Anderson, R Fitzgerald, eds, Ethical research involving children, Florence: UNICEF Office of Research - Innocenti

Cluver, L, Boyes, M, Bustamam, A, Casale, M, Henderson, K, Kuo, K, et al, 2015, The cost of action: Large scale, longitudinal quantitative research with AIDS-affected children in South Africa, in D Posel and F Ross, eds, Ethical quandaries in social research, Cape Town: HSRC Press, 41-56

Dobash, R, Dobash, R, 1992, Women, violence and social change, London: Routledge

Droz, Y, 2006, Street children and the work ethic: New policy for an old moral, Nairobi (Kenya), Childhood, 13, 349-63

Finkelhor, D, 2008, Childhood victimization, Oxford: Oxford University Press

Finkelhor, D, Turner, H, Ormrod, R, 2006, Kid's stuff: The nature and impact of peer and sibling violence on younger and older children, Child Abuse \& Neglect 30, 1401-21

Finkelhor, D, Hamby, SL, Ormrod, R, Turner, H, 2005, The Juvenile Victimization Questionnaire: Reliability, validity, and national norms, Child Abuse \& Neglect 29, 383-412

Finkelhor, D, Ormrod, R, Turner, H, Holt, M, 2009, Pathways to poly-victimization, Child Maltreatment 14, 316-29

Gigengack, R, 2008, Critical omissions: How street children studies can address self destructive agency, in P Christensen and A James, eds, Research with children, 2nd edn, New York: Routledge, 205-19

Graham,A, Powell, M, Taylor, N, Anderson, D, Fitzgerald, R, eds, 2012, Ethical research involving children, Florence: UNICEF Office of Research - Innocenti

James, A, Prout,A, 1997, Constructing and reconstructing childhood: Contemporary issues in the sociological study of childhood, 2nd edn, Abingdon: Routledge

James, A, Jenks, C, Prout, A, 1998, Theorizing childhood, Oxford: John Wiley \& Sons

Jenks, C, 1996, Childhood, Abingdon: Psychology Press

Katz, E, 2015a, Domestic violence, children's agency and mother-child relationships: Towards a more advanced model, Children \& Society 29, 1, 69-79

Katz, E, 2015b, Recovery-promoters: Ways in which children and mothers support one another's recoveries from domestic violence, British Journal of Social Work 45, 1, 1i153-i169

Katz,E, 2016, Beyond the physical incident model: How children living with domestic violence are harmed by and resist regimes of coercive control, Child Abuse Review 25, 1, 46-59

Kelly, L, 1988, Surviving sexual violence, Oxford: Polity

Krug, E, Mercy, J, Dahlberg, L, Zwi, A, 2002, The world report on violence and health, Lancet 360, 1083-8

Lansdown, G, O'Kane, C, 2014, A toolkit for monitoring and evaluating children's participation, London: Save the Children

Lombard, N, 2013,Young people's temporal and spatial accounts of gendered violence, Sociology 41, 6, 1136-51

Lombard, N, 2014, 'Because they're a couple she should do what he says': Justifications of violence: Heterosexuality, gender and adulthood, Journal of Gender Studies 241-53

Lombard, N, 2015, Young people's understandings of men's violence against women, Farnham: Ashgate 
Mahati, ST, 2012, Children learning life skills through work: Evidence from the lives of unaccompanied migrant children in a South African border town, in G Spittler and M Bourdillon, eds, African children at work: Working and learning in growing up for life, Berlin: LIT Verlag

Mahati, ST, 2015, The representations of childhood and vulnerability: Independent child migrants in humanitarian work, Doctoral dissertation, Johannesburg: University of Witwatersrand

Meltzer, H, Doos, L, Vostanis, P, Ford, T, Goodman, R, 2009, The mental health of children who witness domestic violence, Child \& Family Social Work 14, 491-501

Meinck, F, Cluver, LD, Boyes, ME, 2015a, Household illness, poverty and physical and emotional child abuse victimisation: Findings from South Africa's first prospective cohort study, BMC Public Health 15, 444

Meinck, F, Cluver, LD, Boyes, ME, 2015b, Longitudinal predictors of child sexual abuse in a large community-based sample of South African youth, Journal of Interpersonal Violence, doi:10.1177/0886260515596331

Meinck, F, Cluver, LD, Boyes, ME, Loening-Voysey, H, 2016, Physical, emotional, and sexual abuse of children in South Africa: Incidence, prevalence, perpetrators, and locations, Journal of Epidemiology and Community Health.

Mirlees-Black, C, 1995, Estimating the extent of domestic violence: Findings from the 1992 British Crime Survey, Home Office Research Bulletin 37, 1-9

Morrow,V, 2003, Perspectives of children's agency within families: A view from the sociology of childhood, in L Kuczynski, ed, Handbook of dynamics in parent-child relations, London: Sage Publications, 109-29

Murray, SA, Kendall, M, Carduff, E, Worth, A, Harris, FM, Lloyd, A, et al, 2009, Use of serial qualitative interviews to understand patients' evolving experiences and needs, BMJ 339, b3702, 958-62

Oliphant, AE, Kuczynski, L, 2011, Mothers' and fathers' perceptions of mutuality in middle childhood:The domain of intimacy, Journal of Family Issues 32, 1104-24

Pinheiro, PS, 2006, World report on violence against children, Florence: UNICEF

Radford, L, 2012, Re-thinking children, violence and safeguarding, London: Bloomsbury Radford, L, Ellis, J, 2012, Offering children confidentiality in research: What are the limits?, in J Fleming and T Boeck, eds, Involving children and young people in health and social care research, London: Routledge, 118-26

Radford, L, Hester, M, 2015, More than a mirage? Safe contact for children and young people who have been exposed to domestic violence, in N Stanley and C Humphreys, eds, Domestic violence and protecting children: New thinking and approaches, London: Jessica Kingsley Publishers

Radford, L, Corral, S, Bradley, C, Fisher, HL, 2013, The prevalence and impact of child maltreatment and other types of victimization in the UK: Findings from a population survey of caregivers, children and young people and young adults, Child Abuse \& Neglect 37, 801-13

Radford, L, Corral, S, Bradley, C, Fisher, H, Bassett, C, Howat, N, Collishaw, S, 2011, Child abuse and neglect in the UK today, London: NSPCC (www.nspcc.org.uk/ childstudy)

Rutherford, B, 2008, Zimbabweans living in the South African border-zone: Negotiating, suffering, and surviving, Concerned Africa Scholars Bulletin 80, 2, 36-42 
Stoltenborgh, M, Bakermans-Kranenburg, MJ, van Ijzendoorn, MH, Alink, LRA, 2013, Cultural-geographical differences in the occurrence of child physical abuse? A meta-analysis of global prevalence, International Journal of Psychology 48, 81-94

Tew,J, Ramon, S, Slade, M, Bird,V, Melton, J, Le Boutillier, C, 2012, Social factors and recovery from mental health difficulties: A review of the evidence, British Journal of Social Work 42, 443-60

UNICEF, 1989, United Nations Convention on the Rights of the Child (UN CRC), New York: UNICEF

UNICEF, 2014, Hidden in plain sight: A statistical analysis of violence against children, New York: UNICEF

WHO (World Health Organization), 2014, Global status report on violence prevention, Geneva:WHO 